\title{
Poetry, Environment and the Possibility of Future. A Review of Sam Solnick's Poetry and the Anthropocene: Ecology, Biology and Technology in Contemporary British and Irish Poetry (Abingdon: Routledge, 2017)
}

The development of the field of ecocriticism has gained momentum over the last decade, with a number of publications having redefined and re-mapped what have until recently been held as crucial insights. One thinks particularly of Timothy Morton's The Ecological Thought and Timothy Clarke's Ecocriticism on the Edge but also of the publications of Hannes Bergthaller and Hubert Zapf. Among the genres of literary production that matter to the ecological paradigms poetry has been given increased attention after a period in which it was prose that provided the impetus for an increased commitment to ecocritical investigations (here the work of Graham Huggan, Helen Tiffin and Greg Garrard may be mentioned). While poetry has always stood behind the ecocritical project, given its origins in Romanticism (largely disputed now) and the foundational role of poets like Gary Snyder or Wendell Berry, the contemporary poets clearly needed a more sustained attention in terms of the ecological focus of their writing. Again, here the work of Terry Gifford and, in recent years, Susanna Lindström and Eóin Flannery (both in the Irish context) has been crucial. With the release of Sam Solnick's Poetry and the Anthropocene, the critical scene receives a major study, one which promises to be among the cornerstones of a discipline that is only now coming into its own.

Solnick's monograph is distinguished by its breadth, as he focuses on three quite distinct poets, each representing a different tradition. While Ted Hughes and Derek Mahon are familiar choices for an analysis of poetic responses to the crises that the Anthropocene brings (Gifford and Leonard 
Scigaj are as important to ecocriticism as they are central to the reception of Hughes's work), J. H. Prynne, while by all means germane to the discussion, has received far less critical attention than the previous two in general and as regards ecology in particular. If Hughes represents a naturalism descended from such poets as D. H. Lawrence and W. B. Yeats, which is coupled with a deep devotion to mythical thinking, Mahon is a cosmopolitan poet, whose preoccupation with the environment is closer to the wider conception of deep ecology. Prynne works in an experimental tradition, frequently ascribed to the Modernist projects of Pound and Charles Olson (even though such a designation is less true of his post 1990s work), which is generally alien to the more traditional work of poets like Hughes and Mahon. And yet, Solnick sets little store by traditional distinctions of literary history and reception, hunting for the three poets' ecological preoccupations in lieu of trying to set up a critical ground whereon the three poetries could be regarded as furthering a fundamentally similar intellectual project. He states at the outset that his goal is to "show how Hughes tracks the influence of communicative, agricultural and martial technologies on our relations to our own, and other animals', environments, bodies and behaviours" (12); on the other hand, Mahon's poetry is argued to pitch "too-easy environmentalism," which the poet x-rays through a consistent deployment of irony that in itself is indicated to be a "debilitating force," against "a more realistic, troubling and sometimes blackly comic form of ecological consciousness" (13). Finally, Prynne's work, poetry as well as prose, is employed "as a means through which to frame the question of materiality, intelligibility and quantification that permeate his approaches to biology, environment and poetics" (15). In thus delimited a field, Solnick unravels his argument with a view to demonstrating that "poetry is forced to find new ways of rendering, recalibrating ad mutating the complex relationships between human organisms and the environments that their behaviour and technologies have shaped" (15).

Solnick opens his study with a thorough review of theoretical, scientific and ecocritical literature, highlighting the internal debates and contradictions in the field of ecocriticism and ecology in general. The scope of his coverage is as superb as it is profound and aptly phrased. While chapter one serves the function of laying out the ground for the forthcoming explorations of the three poets' work, it also offers some pertinent insights into the development of ecopoetry from the early 1990s, referring to the work of Cheryl Glotfelty and Scott Slovic (the two thinkers behind the establishment of the Association for the Study of Literature and the Environment, ASLE) and also acknowledging the debt to pioneer critics such as Gifford and Scigaj, with an obligatory introduction of the concepts of Jonathan Bate. It is undoubtedly a merit of 
Solnick's book that although he seems to feel an affinity with notions such as Morton's "embeddedness," which he explains as "asking whether, in its attempt to construct a phenomenology of reengagement and inhabitation, ecocriticism fails to show the complex ways humans are embedded in their universe" (25, see Morton 135-38), he also reconstructs criticism of Morton's ideas by for example Garrard, who warns against Morton's hankering after wilderness epiphanies. The fastidiousness of Solnick's treatment of various approaches to ecopoetics notwithstanding, his crucial contribution comes in his references to experimental ecopoetry, which he concentrates on via a discussion of the critical work of Harriet Tarlo. In the introduction to her 2009 anthology The Ground Aslant, Tarlo suggests that what she calls "radical landscape poetry," a category that comprises poets such as Allen Fisher, Barry MacSweeney and Prynne among others, presents "a more realistic view of nature" (Tarlo 2), one that eschews the oversimplifications of much contemporary post-pastoral poetry (Gifford's term, see Gifford 150-55). By referring to such polarities within the study of environmentally-inclined poetry, Solnick shows intellectual fairness in that he does not elevate his theses by silencing voices of dissent. One is aware that Solnick knows that he is covering a contradictory territory and the poets he is writing about would likely fail to see eye to eye on pretty much anything to do with poetry, even if they might reach a tentative truce on environmental matters. It is with these in mind that he commends the ideas of Zapf and Robert Kaufman in a proposition that amounts to a thesis of his study: "literature helps the reader to see, or perhaps experience, the limitations of the 'status quo concepts' determined by society and this can be a source of social, political or ecological possibility," adding further on that "aesthetic experience is better described not as reintegrating different forms of cultural knowledge within the social whole, but rather as drawing out their incommensurability with each other and with the subject's experience" (52). This claim testifies to Solnick's commitment to dialectics, which I would call negative were it not for the cool attitude that most ecocritics' express towards Adorno; nonetheless, Solnick emphasizes that the crucial aspect of literature, and the three poets' work is particularly important in this respect, is its ability to flesh out contrarious agendas that we tend to overlook in our daily linguistic praxis.

In the chapter on Hughes, Solnick proceeds to identify what he deems to be a frequent misapprehension of his work by critics who see him as abhorring technology, which distracts man from his connection with nature (Solnick 66). This is a rather radical position but it also serves to illuminate a number of allusions scattered across Hughes's writings, not only poetry but also prose, to scientific principles and elements of its 
jargon; this is evident even in his more popular pieces, such as his essay on "Myth and Education," in which he argues that

if the story [myth] is learned well, so that all its parts can be seen at a glance, as if we looked through a window into it, then that story has become like the complicated hinterland of a single word. ... Any fragment of the story serves as the "word" by which the whole story's electrical circuit is switched into consciousness, and all its light and power brought to bear. (Hughes 139)

It is immediately noticeable that the excerpt relies on Hughes's potent use of the metaphor of a myth resembling "the complicated hinterland of a single word" but this same evocation is shot through with ideas taken from the register of science-myths are analyzable into parts and they activate their own "short circuits." This gives credence to Solnick's thesis that Hughes uses technology inconsistently; instead, he seems to realize that it is neither good nor bad but merely endowed with too great an adulation by the general public (he indicates as much in an interesting letter to Philip Larkin, written in November 1985, when Larkin was fast succumbing to cancer; Hughes advises that Larkin consult "a very strange and remarkable fellow," Ted Cornish, who was a healer and whose feats Hughes discusses against "US research into what goes on under a healer's hands" [Reid 503]). In Solnick's reading, Hughes becomes a poet who desires to shake up our accepted modes of thinking rather than have us shift our focus from technology back to nature. There may be moments when the line of argument is tenuous, as in the suggestion that in "Crow Ego," the eponymous bird's reformulation of the mythical material that is used in the composition of the poem "re-tool[s] [the past's myths] for Crow's future-oriented ecological project" (Solnick 96); in what sense the volume pursues an "ecological project," and what the nature of this project is, remain unclear. Even so, Solnick's conclusion grasps what seems to be an important aspect of Hughes's poetic vision:

Hughes, perhaps more clearly in his creative work than his criticism, encourages a sense that art does not just revivify our senses in the manner that early ecocriticism proposed but becomes an engine for mutating new concepts, and thereby new possibilities. This intertwined process of perceptual sensitivity and conceptual possibility means that, for Hughes, art might play a significant role in adapting humans to the environmental crisis. (Solnick 97)

Continuing his investigation, Solnick goes on to address Mahon's poetry, first noting the sustained use of irony as a key trope of his oenvre, and 
then exploring the poet's interest in ecology, which has been growing since the early 1990s. Irony is shown to be both a governing trope in these poems and an injurious swerve from the matters of environmental responsibilities. However, for Solnick, irony as deployed by Mahon in his poems, which focus on anxieties over climate change, constitutes a crucial formal aspect that allows the poems to "offer a series of powerful challenges to readers interested in ecology and poetry" (Solnick 108). The problem that appears to be at issue in this part of his study centres around the idea of how a serious ecological engagement can avoid falling prey to easy dogmatism. In response to that issue, Solnick argues that Mahon's irony matters because it frees "the poetry from the complicity and complacency of simulative politics. In doing so it explores the complex and often troubling relations between concerned individuals and their environment" (129). This is quite evident in how Mahon's engagement with James Lovelock and Lynn Margulis's Gaia hypothesis is played out, so that the simplistic metaphor proffered by the two scientists in the 1970s in Mahon's "Homage to Gaia" (from Life on Earth, 2008) is unravelled in a series of contradictory, or ironical, images that resist being formulated into an agenda. Eóin Flannery has suggested that "the organicism of Lovelock's Gaia theory ... is matched by the sense of poetic integrity across ['Homage to Gaia']" (37), a point that Solnick seems to take issue with even though they both agree that the poet seeks to undermine our complacency and instil, in Flannery's formulation, "artistic self-consciousness in exchanges with non-human ecology" (47). It is also noteworthy that Flannery stresses Mahon's resistance to the onslaught of capitalism, noting that "for Mahon, poetry is the peripheral alternative to the global consensus of commercialism, with its attendant deleterious environmental impacts" (48). Solnick, on an ultimately complementary note in respect to Flannery, claims that "Mahon's germinal ironies search out modes and sites of resistance, qualities within the non-identical, the potentiality and operation of the wasted and the marginalised, consistently calling on his readers to ask what - from microbes to multinationals-is implicated within the interpenetrating scales of his chaos of complex systems and how these might mutate in(to) an as-yet-unconceptualised future" (144). This is an apt transposition of what Hugh Haughton has called Mahon's "ironic conscience" onto the level of ecological awareness of the threats that modernity's rapaciousness in general, and the unhinged consumerism spurred on by capitalist economy in particular pose to the environment.

If Mahon is shown to be interested in questions of scale which Clarke has shown lead to an increasing ambiguity of all attempts at comprehending the issues of ecology, a crisis that he terms "Anthropocene disorder" (Clarke 23), Prynne is the poet crucially preoccupied with problems of 
scalar ambiguities. In an early monograph on Prynne, N. H. Reeve and Richard Kerridge have pointed out that "poetry has not often found a way of representing events beyond the scale of direct, individual perceptionevents too large and slow to be observed, such as geological process of formation or dissolution, or too small and quick, such as the movement of molecules or the immediate reactions of nerve-cells" (5). Furthering this insight, Solnick explains that his reading of Prynne "moves across different scales, moving in space from the processes of gene-expression to pictures of the globe from lunar orbit, and in time form the transhuman communities of prehistory to the marginalised populations dealing with the repercussion of climate change" (148). Taking on Prynne's affinity with Heidegger (an area of Prynne criticism that is relatively well-developed but Solnick's restatement of the correlation between the poet and the philosopher is pithy without being reductive), as well as his critique of de Saussure and his vast intertextual apparatus, Solnick convincingly demonstrates that "the ecological challenge of this contemporary 'carbon season' is ... an extension of [Prynne's] attentiveness to the qualitative and the quantitative in the realm of the organic, something which ... lies at the heart of his poetics" (186). Solnick writes pertinently about Prynne's use of science and how accurately Prynne employs conceptual schemes so as to challenge their apparent objectivity and aloofness from involvement in the ideological strife of the contemporary world. This is best shown in Prynne's High Pink of Chrome but also in Kazoo Dreamboats, a long poem that takes on the matter contradiction as derived from Mao Zedong's essay. It is in the latter that, Solnick argues, Prynne insists with particular emphasis on "think[ing] beyond anthropocentric terms, including the ways the resistance of the world - its conflicting and dynamic materialityexceeds both conceptual thought and technological control" (Solnick 190).

One might point out, however, that despite his pertinent insight into Prynne's avowed search for the destabilization of accepted modes of thought commodification, Solnick overlooks what seems to be a promising connection between Mahon and Prynne. In a relatively short span of time, both poets published essays on huts: Prynne's "Huts" appeared in 2008 and Mahon's "Huts and Sheds" in 2011. It is notable that, adopting different critical methods, Prynne canvassing the history of English language poetry and the popular imagery and Mahon being more meditative in his explorations, they both endorse a view of poetry as a mode of resistance to the reification of thought. Mahon argues that, due to their position at the intersection of the known and the unknown, huts are "sites of reverie," which being "immune to market forces" represent a removed hermitage that "invite[s] us to mine, to mind, our human resources and put ourselves in order" (13). This view of huts tallies with Mahon's point, from “The 
Poetry Nonsense," which Solnick discusses at some length, that poetry nonsense "has no function and no exchange value.... It is indeterminate, marginal, unimportant; and therein lies its importance" (Mahon 33). On the other hand, Prynne argues that "the house of language is not innocent, and is no temple. The intensity of poetic encounter, of imagination and deep insight into spiritual reality and poetic truth, carry with them all the fierce contradiction of what human language is and does" (630). Part of this contradiction is that a word projecting as seemingly innocuous an image as "hut" (one that is "timber-framed and clad with light planks or other local materials, to provide basic shelter, to allow outward watchfulness [originally of grazing animals], in distant or non-social locations, often at language-margins, with a low-raked roof and window-spaces and one door, not a dwelling and not set up for family life but estranged from it and its domestic values" [Prynne 629]) is also underlain with implications of, for example, "watchtowers of divisive and punitive regimes" (Prynne 629). He concludes that "ruin and part-ruin lie about us on all sides," adding that "the poets are how we know this, are how we may dwell not somewhere else but where we are" (631). For Prynne, the importance of poetry lies in its ability to let that which ideology conceals be heard and known, a premise of poetics quite similar to Mahon's urge that poetry's crucial feature is its untranslatability into the prevalent modes of value endowment. The association serves to indicate that the poetic projects Solnick chooses to discuss share an intellectual foundation beyond their interest in ecology.

Such minor omissions notwithstanding, Solnick's monograph is a fine example of literary criticism that seeks to engage wider issues than just poetry's own specific modus operandi. At no point does he end up preaching on behalf of the environment, using the poets' work as a welcome excuse for popularizing an agenda; instead, Solnick works his way painstakingly through the three oewores, picking out the moments of contradiction and imaginary flourishes, which have made the work of Hughes, Mahon and Prynne such a permanent pleasure for so long. If criticism has any role to play in tackling the environmental crisis we are witnessing all around us, it is by being practised in precisely the manner which Solnick masterfully displays in his study.

\section{Works CiTED}

Clarke, Timothy. Ecocriticism on the Edge: The Anthropocene as a Threshold Concept. London: Bloomsbury, 2015. Print.

Flannery, Eóin. Ireland and Ecocriticism: Literature, History, and Environmental Justice. London: Routledge, 2016. Print. 
Gifford, Terry. Pastoral. London: Routledge, 1999. Print.

Hughes, Ted. Winter Pollen: Occasional Prose. London: Faber, 1994. Print. Mahon, Derek. Selected Prose. Oldcastle: Gallery, 2012. Print.

Morton, Timothy. Ecology Without Nature. Cambridge, MA: Harvard UP, 2007. Print.

Prynne, J. H. "Huts." Textual Practice 22 (2008): 613-33. Print.

Reeve, N. H., and Richard Kerridge. Nearly Too Much: The Poetry of J. H. Prynne. Liverpool: Liverpool UP, 1995. Print.

Reid, Christopher, ed. Letters of Ted Hughes. London: Faber, 2007. Print.

Solnick, Sam. Poetry and the Anthropocene: Ecology, Biology and Technology in Contemporary British and Irish Poetry. Abingdon: Routledge, 2017. Print.

Tarlo, Harriet, ed. The Ground Aslant: An Anthology of Radical Landscape Poetry. Bristol: Shearsman, 2009. Print.

Wit Pietrzak is Professor of British and Irish Literature in the Institute of English Studies, University of Łódź. He specializes in modernist and neo-modernist Irish and British poetry and has published several books of criticism, including Levity of Design. Man and Modernity in the Poetry of J. H. Prynne, Ostrożnie, poezja. Szkice o respótczesnej poezji anglojęzycznej [Careful, Poetry. Essays on English-Language Poetry] and, most recently, The Critical Thought of W. B. Yeats.

witpietrzak@wp.pl 